were least happy with the PEP mask, complaining that their chests did not always feel clear after treatment. Independent treatment of this sort requires motivation and self discipline on the child's part, as well as parental supervision, and is probably not suitable for most children under 10 years. For some teenagers it is a valuable and acceptable form of treatment, allowing considerable independence. Older patients might manage satisfactorily with postural drainage and forced expiratory coughing alone-we intend to compare this with PEP mask treatment.

We thank Astra Meditec for the loan of the PEP masks. JT is supported by the Cystic Fibrosis Research Trust.

References

${ }^{1}$ Desmond KJ, Schwent WF, Thomas E, Beaudry PH,
Coates AL. Immediate and long term effects of chest physiotherapy in patients with cystic fibrosis. $J$ Pediatr 1983;103:538-42.

2 Pryor A, Webber BA, Hodson ME, Batten JC. Evaluation of the forced expiration technique as an adjunct to postural drainage in treatment of cystic fibrosis. $\mathrm{Br}$ Med J 1979;ii:417-8.

${ }^{3}$ Falk M, Kelstrup M, Andersen J, et al. Improving the Ketchup bottle method with positive expiratory pressure, PEP, in cystic fibrosis. Eur J Respir Dis 1984;65:423-32.

4 Tønnesen P, Støvring S. Positive expiratory pressure (PEP) as lung physiotherapy in cystic fibrosis-a pilot study. Eur J Respir Dis 1984;65:419-22.

5 Shwachman H, Kulczycki L. Long term study of 105 patients with cystic fibrosis. Am J Dis Child 1958;96:6-15.

${ }^{6}$ Chrispin A, Norman A. The systematic evaluation of the chest radiograph in cystic fibrosis. Pediatr Radiol 1974;2:101-6.

Correspondence to Dr J C Tyrrell, Ward A2, City Hospital, कं Hucknall Road, Nottingham NG5 1PB, England.

Received 26 February 1986

\title{
Severe neonatal pertussis treated by salbutamol
}

\author{
A Y-C TAM AND C-Y YEUNG
}

Department of Paediatrics, Queen Mary Hospital, University of Hong Kong, Hong Kong

SUMmary Two neonates with severe culture proven pertussis were successfully treated with salbutamol $0.5 \mathrm{mg}$ three times daily. There was a demonstrable decrease in the total number of coughing spasms, their mean duration and severity. In one baby this was shown by the transcutaneous oxygen tension measurements.

Vaccination against pertussis has done much to decrease the incidence and mortality of the disease. Complete eradication is still not possible, however, with the present vaccine. Moreover, the epidemiology of the disease has changed, in that it now affects more young infants who are too young to receive the immunisation. ${ }^{1}$ Although treatment with erythromycin successfully kills the bacterium, it can alleviate the coughing spasms only if given very early. In young infants coughing spasms are not only distressing but also related to complications. Hence the search for treatment of the cough spasms of pertussis is still continuing. Beta adrenergic blockade in pertussis has been shown in children. ${ }^{2}$ Various workers have shown the effectiveness of salbutamol, a beta 2 agonist, in alleviating the coughing spasms in pertussis. ${ }^{3}$ We report the success of using salbutamol in two neonates with culture proven Bordetella pertussis infection.

\section{Case reports}

Case 1. A 14 day old girl was admitted with a one $\overrightarrow{\overrightarrow{0}}$ day history of coughing spasms associated with $\exists$ cyanosis. In between the spasms she remained pink and well. Her white blood cell count was $30 \cdot 8 \times 10^{9} / 1$ (lymphocytes $70 \%$ ). Pernasal swab grew Bordetella pertussis. Treatment with erythromycin was started on admission. Salbutamol was also given at a dose of $0.5 \mathrm{mg}$ three times daily. The infant was nursed in the intensive care unit with an attending nurse by $\delta$ the cot side who would record in detail the onset and $₹$ duration of coughing spasms. Manipulation and pharyngeal suction was kept to a minimum. Oxygen was administered through an oxygen funnel during the paroxysms. The child was kept in the intensive $\vec{N}$ care unit for a total of 13 days. The number of 0 coughing spasms decreased slowly from 31 on day $1 \stackrel{N}{N}$ of admission to 20 on day 4 and further to 10 on day 8. The mean duration of coughing spasms, however, was markedly decreased by treatment with salbuta- 0

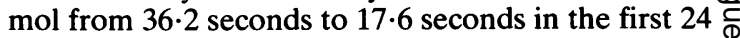
hours of administration of salbutamol (Figure). The $\stackrel{\oplus}{\rightarrow}$ treatment with salbutamol was continued for a total 0 of 10 days. Her subsequent recovery was uneventful.

Case 2. A 20 day old girl had a cough for two days that was deteriorating. On admission she was having 


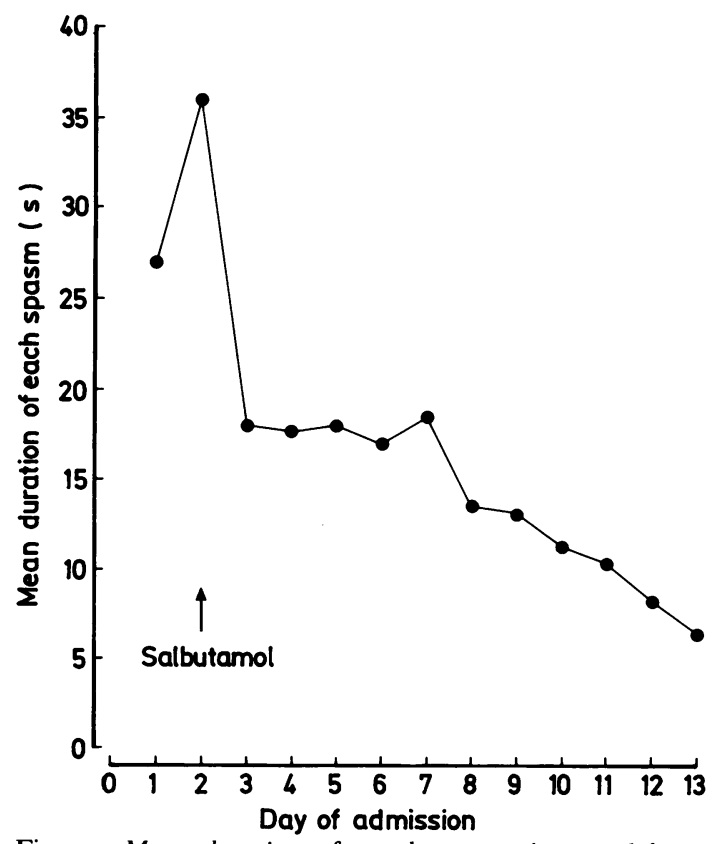

Figure Mean duration of cough spasms in case 1 before and after treatment with salbutamol.

very frequent paroxysms with cyanosis and an occasional whoop. Her white blood cell count was $19 \cdot 8 \times 10^{9} / 1$ with $68 \%$ lymphocytes, and the pernasal swab was confirmatory of pertussis. She was also given erythromycin. Treatment with salbutamol at a dose of $0.5 \mathrm{mg}$ three times daily was started after a period of observation in the intensive care unit. The attending nurse recorded the number of periods of continued coughing and tried to time the duration. The baby was attached to a Roche transcutaneous oxygen and carbon dioxide tensions monitor for 18 hours before and after the beginning of treatment with salbutamol. Supplemental oxygen was given through a funnel whenever her transcutaneous oxygen tension fell below $50 \mathrm{mmHg}$. Transcutaneous oxygen was in the normal range in between coughing spasms. A tracing of the transcutaneous oxygen and carbon dioxide measurements was kept. A summary of observations made before and after treatment is shown in the Table. There was a pronounced reduction of the total number of spasms after treatment with salbutamol was begun. Moreover, the number of severe episodes, as judged by the number of times that the transcutaneous oxygen tension fell below $50 \mathrm{mmHg}$, was also less. Her paroxysms were so frequent that it was practically impossible to record the duration of each attack. She recovered progressively so that, although she was still coughing frequently by day 2
Table Coughing spasms in case 2 before and after treatment with salbutamol

\begin{tabular}{|c|c|c|}
\hline & $\begin{array}{l}18 \text { hours } \\
\text { before }\end{array}$ & $\begin{array}{l}18 \text { hours } \\
\text { after }\end{array}$ \\
\hline Total coughing spasms & 221 & 124 \\
\hline Means spasms per hour & $12 \cdot 3$ & 6.9 \\
\hline \multirow{2}{*}{$\begin{array}{l}\text { Episodes of transcutaneous oxygen } \\
\text { tension }<50 \mathrm{mmHg}\end{array}$} & & \\
\hline & 15 & 7 \\
\hline
\end{tabular}

after admission, she was not cyanotic anymore. The treatment with salbutamol was continued for two weeks. She was normal on follow up four months later.

\section{Discussion}

It is now known that the clinical syndrome of pertussis is caused by the toxins produced, ${ }^{4}$ the principle one of them being the pertussis toxin. It has been found to be responsible for enhanced cellular hypersensitivity to agents like histamine and serotonin, abnormal metabolic alterations like hypoglycaemia, and lymphocytosis-leucocytosis. These responses were attributed to a beta adrenergic blockade upsetting the balance between the vagal and adrenergic systems. ${ }^{2}$

The evidence for treatment with salbutamol being effective in controlling the cough paroxysms is largely uncontrolled and in children of older age groups. As far as we know, our two patients are the youngest in the published reports that were successfully treated with salbutamol. The mechanism of action is not entirely clear. Although the smooth muscle with beta ${ }_{2}$ receptors are reported to be absent in the small airways of infants, ${ }^{5}$ salbutamol might act on the muscular trachea and bronchi, which are major sites for toxin fixation. Moreover, other mechanisms like mast cell mediator release and mucociliary clearance might be involved. Obviously, randomised controlled trials would be necessary to ascertain its effect. The pharmacokinetics of salbutamol in young infants is not well understood. Although no side effects were noticed during treatment in our infants, it is still best reserved for the severer cases. The transcutaneous oxygen and carbon dioxide tensions monitor is one useful adjunct to document objectively the coughing paroxysms and their effects, especially for the young infant who is severely affected. Nevertheless, skilled nursing and close observation are still the essentials for the management of affected infants.

\footnotetext{
References

${ }^{1}$ Nelson JD. The changing epidemiology of pertussis in young
} 
infants: the role of adults as reservoirs of infection. Am J Dis Child 1978;132:371-5.

2 Badr-el-din MK, Aref $\mathrm{GH}$, Mazloum $\mathrm{H}$, et al. The betaadrenergic receptors in pertussis. J Trop Med Hyg 1976;79: 213-7.

${ }^{3}$ Badr-el-din MK, Aref GH, Kassem AS, Abdel-Moneim MA, Abbassy AA. A beta-adrenergic stimulant, salbutamol, in the treatment of pertussis. J Trop Med Hyg 1976;79:218-9.
${ }^{4}$ Pittman M. The concept of pertussis as a toxin-mediated disease. Pediatr Infect Dis 1984:3:467-86.

${ }^{5}$ Lenney W, Milner AD. At what age do bronchodilator drugs work? Arch Dis Child 1978;53:532-5.

Correspondence to Dr A Y-C Tam, Department of Paediatrics, University of Hong Kong, Queen Mary Hospital, Hong Kong.

Received 5 February 1986

\title{
Nebulised ipratropium and salbutamol in asthma
}

\author{
J STORR AND W LENNEY
}

Royal Alexandra Hospital for Sick Children, Brighton

SUMmARY Treatment with nebulised salbutamol or a mixture of salbutamol and ipratropium was given to 138 children. Length of hospital stay and number of nebulised doses required did not differ. In severe asthma response was greater with salbutamol alone. In mild asthma response was greater with combined treatment.

Ipratropium bromide is an effective bronchodilator in children. ${ }^{1-3}$ There are potential advantages in combining it with a beta adrenergic agent in treating asthma. ${ }^{2}$ We aimed to discover whether the addition of ipratropium to treatment with salbutamol would lead to a therapeutic response greater than that attainable with salbutamol alone.

\section{Patients}

All patients admitted to our hospital because of asthma between October 1984 and March 1985 were studied. There were 138 children, 95 boys and 43 girls. Their ages ranged from 11 months to 15 years, with a mean of 5.0 years. Thirteen were aged under 18 months. One hundred and five $(76 \%)$ had had one or more previous admissions for asthma.

\section{Methods}

The children were randomly allocated to a salbutamol or a combined treatment group. The former received $5 \mathrm{mg}$ salbutamol and the latter $5 \mathrm{mg}$ salbutamol mixed with $0.25 \mathrm{mg}$ ipratropium in each nebuliser. Nebuliser solutions were of equal tonicity and were administered double blind.

There were 70 patients in the salbutamol group and 68 in the combined treatment group. Standardised admission sheets were used, which incorpor- ated a score of clinical severity (scale: $0-10)$. The mean admission scores in each group were almost identical (4.69 and 4.52). The age and sex distribution were similar, as were the past history, family history, parental smoking history, and drugs used before admission.

Nebulisers were given within set limits at the discretion of the nursing staff. Steroids were given to children not responding satisfactorily to nebulised treatment, and intravenous aminophylline was given to children in severe respiratory distress.

In those old enough to produce accurate readings peak expiratory flow rates were measured immediately before and 20 minutes after treatment (except at night). Percentage changes in the peak expiratory flow rate were stratified so that responses were compared at similar degrees of severity. All statistics were analysed using the Wilcoxon rank sum method for unpaired data.

\section{Results}

Mean length of hospital stay and number of doses of nebulised medicine required were similar in each group (Table 1). Thirty five patients receiving

Table 1 Length of admission and treatment required in the two treatment groups

\begin{tabular}{lll}
\hline & Treatment group & \\
\cline { 2 - 3 } & Salbutamol & $\begin{array}{c}\text { Salbutamol and } \\
\text { ipratropium }\end{array}$ \\
\hline $\begin{array}{l}\text { No of patients } \\
\begin{array}{l}\text { Mean length of } \\
\text { admission (days) }\end{array}\end{array}$ & 70 & 68 \\
$\begin{array}{l}\text { Mean total no } \\
\text { of nebulisers given }\end{array}$ & $2 \cdot 8$ & 3.0 \\
$\begin{array}{l}\text { No treated with: } \\
\text { Steroids } \\
\text { Intravenous aminophylline }\end{array}$ & $8 \cdot 6$ & 9.3 \\
\hline & 1 & 19 \\
\hline
\end{tabular}

